\title{
The Extent to Which Force Majeure Applies to Contractual Obligations in The Shadow of the Corona Pandemic
}

\author{
Ammar Shakier Mahmood*, Ahmed Safaa Yahya \\ Department of Law, Al-Maarif University College, Anbar, Iraq \\ *ammar_sh91@yahoo.com
}

\begin{abstract}
:
This pandemic Covid-19 or Corona virus is an urgent foreign cause to the whole world, including the parties to the contractual relationship who had no hand in the occurrence of that pandemic and are not able and able to avoid their effects, regardless of the efforts they have made in that. Mostly (a foreign force majeure led to obstructing the implementation of the obligation and making the debtor's implementation of his obligation impossible. Through this, the researcher aims to explain the effect of this adaptation on contracts. The researcher committed to his research in the comparative descriptive approach in explaining the concept of the pandemic from a linguistic standpoint and its effects on commitment in general and contractual in particular And the researcher reached to impart the proper legal adaptation of the pandemic to which most of the countries of the world as well as the French judiciary go, which is that the pandemic "covid 19" arising from the spread of the Corona virus is a foreign reason that represents a force majeure that prevents the debtor from carrying out his commitment and makes its implementation of his commitment impossible.
\end{abstract}

Keywords: Corona Virus; Covid-19 Pandemic; Contractual Commitment; Force Majeure. 


\section{مدى انطباق حالة القوة القاهرة على الالتزامات التعاقدية في ظل جائحة كورونا \\ م.م عحار شاكر محمود فيصل "، م.م أحمد صفاء يحيى الخطيب \\ قسم القانون، كلية المعارف الجامعة، الأنبار، العراق \\ *ammar_sh91@yahoo.com}

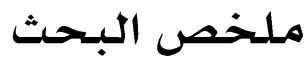

جائحه كوفيد - 19 أو فيروس كورونا هي سبب اجنبي طارئ على العالم اجمع ومنهم أطراف العلاقة العقدية الذين لم يكن لهم يد في حدوث تلك الجائحة و ليس بمقدورهم ووسعهم تلافي أثارها مها بذلو ا في ذلك من جهود وعليه لا بد من بيان النكييف القانوني لتلك الجائحة وهوى على الأغلب (قوه قاهره أجنبيه أدت إلى تعطيل تنفيذ الالنزام وجعل تنفيذ المدين لالتزامه مستحيلا. ويهدف الباحث من خلال ذلك إلى بيان أثر هذا التكييف على العقود. إلتزم الباحث في بحثه المنهج الوصفي المقارن في بيان مفهوم الجائحة من الناحية اللغوية وبيان آثارها على الالتزام عامة والعقدي خاصة ، وتوصل الباحث الى إضفاء التكييف القانوني السليم على الجائحة و الذي تذهب إليه أغلب دول العالم فضلا عن القضاء الفرنسي وهو أن جائحة "COVID19" الناشئة عن انتشار فيروس كورونا هي سبباً اجنبياً يمثل حاله قوه قاهره تمنع المدين من تنفيذ التزامه وتجعله

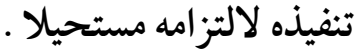

الكلهات المفتاحية: كورونا فيروس، جائحة كوفيد-19، الالتزام التعاقدي، القوة القاهرة. 


\section{المقدمة}

منذ اللحظة الأولى للإعلان عن ظهور فيروس "كورونا" أو (كوفيد-19)، (Corona Virus Disease - 2019) في مدينة ووهان مقاطعة هوبي "Hubie Province" في دولة الصين، قارة أسيا مرورا بأنتشاره السريع في العالم وتصنيفه كجائحة عالمية تهدد البشرية جمعاء وصولاً المى يومنا هذا يواصل الفايروس أثارة الرعب والذعر في النفوس ويكصد أرواح الناس كباراً وصغارًا رجالاً ونساء، ولم يقف عند هذا الحد بل امتدت آثاره لتشمل كافة نو احي الحياة سواء الناحية الاجتماعية أو الاقتصادية أو القانونية، وغيرها الكثير. للحفاظ على الصحة العامة وسلامة المواطنين والشعوب في الدول شرعت الحكومات في كافة أنحاء العالم دون استثناء باتخاذ إجراءات وقائية واحترازية اشتملت على التباعد الاجتماعي، والبقاء في المنازل، وحضر التجوال والتنقل بين المدن لا بل وحتى المناطق داخل المدن وعدم الخروج إلا للضرورة القصوى الأمر الذي بدوره أعاق الكثير من الناس عن الوفاء بالتزاماها المختلفة وما يهمنا هنا في هذه الدراسة هي الالتزامات التعاقدية الناشئة عن العقد كمصدر من مصادر الالتزام وفقا للقانون، وكيفية إيفاء المدين بها في ضل هذه الظروف التي افرزةا الجائحة.

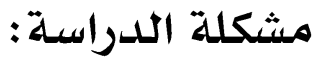

نتيجة للإنتشار الو اسع والخطير لـ "فيروس كورونا" وما نتج عنه من أثار قانونية كان من أهمها إعاقة الأفراد والمجتمعات بل وحتى الدول والمنظلات الدولية كافة عن الوفاء بالتزاماتها التعاقدية الناشئة في ضل القانون على اختلاف فروعه الأمر الذي يدفع إلى إثارة التساؤل الآتي: ما هو أثر جائحة كوفيد - 19 أو فيروس كورونا على الالتزامات الناشئة عن العقد في ضل القانون الخاص (القانون المدني)؟، وهو التساؤل الذي سنجيب عنه خلال الدراسة.

أسئلة الدراسةة : أ. أ. ما هي الجائحة؟ وما هو الالتزام التعاقدي؟ 
ب. هل يجبر المدين على تنفيذ التزامه التعاقدي وفقاً للقانون في ضل هذه الظروف؟ وما هي مسؤوليته عن

$$
\text { عدم التنفيذ؟ }
$$

ت. هل تصدى المشرع بالتنظيم القانوني لمثل هذه الظروف في القوانين الوطنية؟

$$
\text { أهداف البـحث: }
$$

نهدف إلى بيان الأثث الذي تركته الجائحة على الالتزامات التعاقدية ،

تسليط الضوء على المعالجة القانونية التي نص عليها المشرع في القوانين الوطنية في مثل هذه الظروف .

\section{منهجية البحث:}

حرص الباحثان على استعال المنهج الوصفي المقارن عند بيان المقصود بالجائحة والالتزام التعاقدي ومدى معالجة المشرع لأثار الظروف الاستثائية على الالتزام خاصة مستقرئين آراء الفقه القانوني في ذلك مستنبطين منه النتائج والتوصيات.

\section{المبـحث الأول: مفهوم جائحة كورونا والالتزامات العقدية:}

كثيرا ما سمعنا في هذه الحياه منذ القدم وحتى يو منا هذا عن الأوبئة والأمراض التي تبدأ في زمن وتنتشر لحين ظهور دواء أو لقاح لها فتبدا بالانحسار ثم تنتهي إلا أنه قليلاً ما ورد الى مسامعنا أو تم تداوله على ألسن الناس مصطلح جائحه عالميه كونه تعبير علمي طبي دقيق يعرفه أهل الاختصاص من أفراد القطاع الصحي وذوي المهن الطبية والمؤسسات و المنظمات الصحية الوطنية والدولية على حد سواء. فضلاً عن ذلك تشير معظم كتب الفقه القانوني في بجال القانون الخاص إلى مصادر الالتزام ومن أهم تلك المصادر وأو لها العقد باعتباره مصدراً رئيسيا واسع الانتشار لإنشاء الالتزامات في ذمة أطرافه وهو الأمر الذي يدفعنا إلى إثاره التساؤلات التالية:

- ما - ما المقصود بالجائحة من الناحية اللغوية والطبية؟

- ما المقصود بالعقد والالنزام في اللغة والفقه القانوني؟ 


\section{المطلب الأول : الجائحة يفِ اللغة والاصطلاح الطبي:}

الجائحة لغةً:

جأئحة، جائحَ: اسم فاعل مؤنث مصدره الفعل (جَاحَ)، وجمعها جوائح، ويراد بها المصيبة أو الداهية أو النازلة التي تحل بالفرد أو الجماعة أو البلد فتصيبهم بها يكرهون ، ويكون اثرها عامأ على الشيء الذي تصيبه.

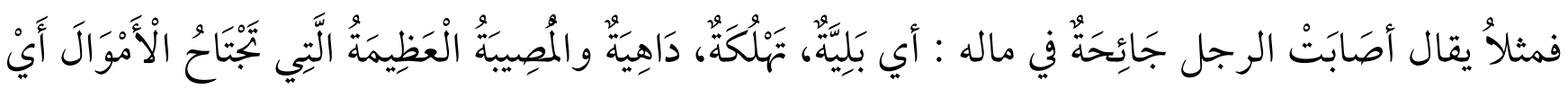

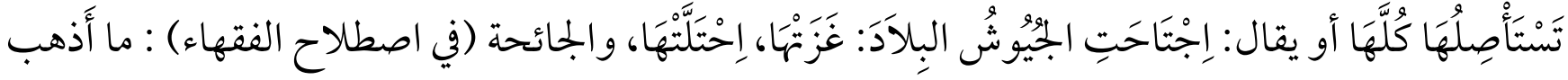
الثمرَ أَو بعضَه من آفِة سماوية(1)، ويقال: رفْع الحوائج أشدُّ من نزول الجُوائح. ويقول الشاعر الفرزدق:

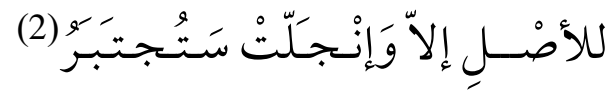

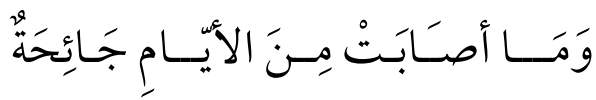

$$
\begin{aligned}
& \text { وقال الشاعر أبن الرومي: }
\end{aligned}
$$

لم نبـك مـنـك على دنيـا ولا ديـن (3)

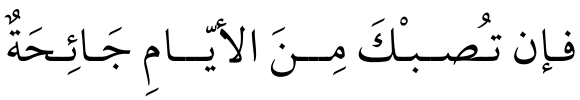

$$
\begin{aligned}
& \text { الجائحة في الاصطلاح الطبي: }
\end{aligned}
$$

منذ الإعلان عن فيروس كورونا في الصين في ديسمبر 2019م مروراً بإعلانه جائحة عالمية من قبل منظمه الصحة العالمية في مارس 200 وصو لاً إلى يومنا هذا فقد أثار الفيروس منذ انتشاره وحتى اليوم الكثير من التساؤلات سوى على المستويات الرسمية كالمنظلات العالمية الدولية و على مستوى الدول والحكومات أو بشكل غير رسمي بين الأفراد في المجتمعات حيث لا زال البعض يتساءل عن ماهية الجائحة من الناحية الطبية وهو الأمر الذي سنجيب عنه في هذه الفقرة. فيروس كورونا هو من سلالة واسعه من فيروسات كورونا التي تسبب الأمر اض للإنسان والحيو ان على حد سو اء وتتسبب هذه الفيروسات في الأمراض التنفسية التي تتراوح حدتها من نزلات برد خفيفة وصولاً إلى نزلات البرد الشديدة التي قد تؤدي إلى الوفاه في حاله تطور الحالة إلى متلازمة تنفسيه حاده. يقصد بالفيروسات المعدية أو السارية (Infectious Diseases) تلك الأمراض التي تنتقل بين الأشخاص بواسطه وسائل متنوعه منها ملامسه المصاب بشكل مباشر أو التعرض للرذاذ المتطاير الذي يخرج من جسم 
الشخص المصاب أو عن طريق الحشرات الناقلة وغير ذلك من الوسائل (4) وهنا لا بد من التساؤل عن المقصود بجائحة " COVID - 19" أو فيروس كورونا وهو فيروس من سلاله فيروسات عائله كورونا التي تسبب المتلازمة التنفسية ويعد من أشدها أثراً فقد أدى إلى حدوث حالات وفاه في الصين وغيرها من الدول التي أنتشر فيها وما لبث أن ازدادت سرعه أنتشاره في جميع الدول فنتشر في قارتين فبادرة منظمه الصحة العالمية في 11 / مارس/ COVID 20 أو فيروس كورونا وياء عالمي حيث أنتشر في ثلاث 19 إلى إعلاث قارات أسيا واوروبا و أمريكا. أما أعراض هذه الجائحة كوفيد 19 او فيروس كورونا فتشمل الأعراض الأكثر شيوعاً وهي الحمى والإرهاق والسعال الجاف والتي تعد أكثر الأعراض شيوعا بين أغلب الحالات وقد يصاحبها في بعض الحالات ألام وأوجاع شديدة في الجسد وانحطاط في القوه البدنية وقد يتصاحب معها الصداع والتهاب في الجيوب الأنفية وآلام في الجهاز التنفسي العلوي وقد يصاحب ذلك فقدان لحاسة أو أخرى كحاسة التذوق و الشم وغيرها من الأعر اض ، و قد تمتد في بعض الحالات لتصبح تغير في الوان الأطر اف العليا والسفلى (5).

\section{المطلب الثاني: العقد فٍِ اللغلة العربية والفقه القانوني:}

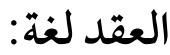

ير اد بالعقد في اللغة الجمع بين شيئين فيقال عقد الحبل إذا جمع بين طرفيه ، كما يطلق على الربط من جانب

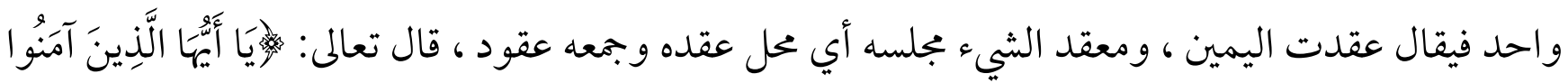

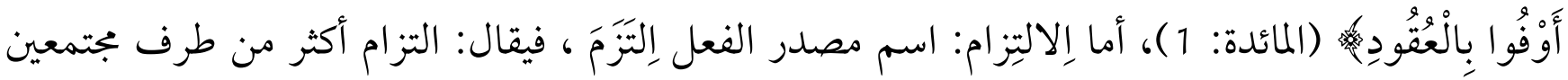
ومنفردين بتحقيق شيء أو عمل شيء ، ويقال: لَزَمَ القَانُونُ : وَجَبَ حُكْمُهُ ، إذاً يراد بالالتزام.

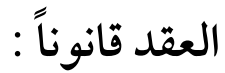

ير اد بالعقد في الفقه القانوني هو تطابق ارادتين أو أكثر على ترتيب آثار قانونية سواء كانت هذه الآثار هي أنشاء التزام أو نقله أو تعديله أو أنهائه(6)، أما المقصود بالعقد قانوناً فبينته المادة (3 7) من القانون المدني العراقي بنصها (ارتباط الإيجاب الصادر من أحد المتعاقدين بقبول الآخر على وجه يثبت أثره في المعقود عليه) يتضح 
من ذلك أن العقد وفقا للقانون العراقي هو تطابق إرادتين وليس إرادة واحدة، كما تتجلى في التعريف النزعة الموضوعية المأخوذة من الفقه الإسلامي.

تحديد منطقة العقد: ليس كل اتفاق بين ارادتين يراد به إحداث أثر قانوني يعتبر عقداً بل يجب أن يكون هذا التو افق بين الإرادات و اقعاً في نطاق القانون الخاص وفي دائرة القانون المدني وفي صلب المعاملات المالية.

\section{المبحث الثاني: التكييف القانوني لأثر جائحة كورونا على الالتزام العقدي:} انتشرت في العقود الأخيرة الكثير من الأمراض والأوبئة التي هددت الأمن الصحي العالمي للكثير من دول العالم وانتجت الكثير من الأثار على مختلف الصعد وأهمها الصعيد القانوني بدءا من وباء سارس (SARS) في عام 2003 م ، وفيروس انفلونزا الطيور (H1N1) في عام 2009م، وفيروس (EBOLA) عام 2014م وصصولاً إلى فيروس كورونا "Covid - 19" , (Corona Virus Disease - 2019) الذي نعيش تحت وطأته في هذه الأيام نسال الله أن يسلمنا وجميع العالم منه ويأذن بزواله عن البشرية جمعاء أنه ولي ذلك. إذ لا زالت أثاره حاضره في خختلف الصعد ومنها الجانب القانوني والمتمثلة في أثار فيروس كورونا على الالتزامات الناشئة عن العقد كمصدر من مصادر الالنزام. هنا لا بد من التساؤل عن مدى اعتبار جائحه كورونا قوه قاهره، وما هو التكييف القانوني الدقيق لأثار هذه الجائحة على الالتزام العقدي؟ ، وهو الأمر الذي سنبينه في هذا المطلب في فروعه الآتية:

\section{المطلب الأول : القوة القاهرة فِّ القانون المدني العراقي:}

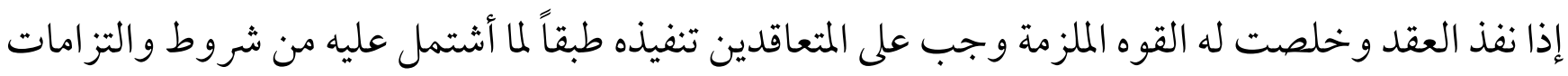
إعمال لمبدأ قانوني عالمي مستقر وثابت والمتمثل بمبدأ العقد شريعة المتعاقدين(7)، والذي أضحى اليوم من الركائز القانونية العالمية التي ينص عليها التنظيم القانوني للعقود في غختلف الأنظمة القانونية في العالم، وهذا المبدأ هو نتيجة حتميه لمبدأ (سلطان الإرادة)، ويراد بمبدأ العقد شريعة المتعاقدين (تنفيذ العقد المبرم بين 
المتعاقدين بها أشتمل عليه جميعاً دون تعديل أو تغيير فيه)، وقد نص المشرع العراقي على ذلك في المادة

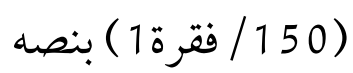

"1 - يجب تنفيذ العقد طبقاً لما اشتمل عليه وبطريقة تتفق مع ما يو جبه حسن النية. 2- ولا يقتصر العقد على الزام المتعاقد بها ورد فيه ، ولكن يتناول ايضاً ما هو من مستلزماته وفقاً للقانون

$$
\text { والعرف والعدالة بحسب طبيعة الالتزام" }
$$

وهذا المبدأ يمكن الخضوع له وإعحاله في حاله الظروف العادية أي بمعنى استمرار الظروف التي كانت سائدة لحظه إبرام العقد وتتجلى أهميه هذه المسألة بوضوح في حال كان العقد المبرم من قبيل العقود المستمرة أي ذلك النوع من العقود الذي يجتاج في تنفيذه إلى مده زمنيه معينه تتم على مراحل متتاليه ولا يمكن تنفيذه دفعه واحده كما هو الحال بالنسبة للعقد الفوري. في مرحلة تنفيذ العقد المستمر قد تطر أ ظروف أو أسباب أجنبيه تمنع المدين من تنفيذ التزامه أو تجعل تنفيذه لالتزامه يهدده بخساره فادحه ويكون التنفيذ مرهقاً له أو يجعل تنفيذه للالتزام مستحيلاً لا مرهقاً، ومن الأسباب الأجنبية التي تؤدي إلى تغير الظروف والخروج على قاعده العقد شريعة المتعاقدين القوه القاهرة فقد نص المشرع العراقي صراحه على القوه القاهرة في المادة (211) منه بنصه" اذا اثبت الشخص ان الضرر قد نشأ عن سبب اجنبي لا يد له فيه كآفة سماوية او حادث فجائي او قوة قاهرة او فعل الغير او خطأ المتضرر كان غير ملزم بالضمان ما لم يوجد نص أو اتفاق على غير ذلك."(8) إلا أن المشرع العراقي لم يحدد المقصود بالقوة القاهرة فحاول الفقه القانوني تحديد المقصود بالقوة القاهرة مما أدى إلى تعدد التعارف إذا عرفها بعض من الفقه العراقي بأنه (ظرف أجنبي عن الدائن والمدين (المتعاقدين) والغير كالحروب وما ينجم عنها من أحداث ماديه وازمات اقتصاديه أو صدور تشريع أو قانون أو امر أجنبي ينبغي نفاذه أو كوارث طبيعية أو انتشار جائحه (وباء)) (9)، ويمكن إجمال ذلك بالقول أن (القوه القاهرة هي ضرف استثنئي أجنبي عن المتعاقدين لا يمكن تفاديه يجعل تنفيذ الملتزم المدين بالعقد لإلتز امه مستحيلاً). يمكن من ذلك استنتاج شروط لابد من توافرها لاعتبار السبب الأجنبي قوه قاهرة ، وهذه الشروط هي: 


$$
\begin{aligned}
& \text { أو لا : عدم امكانيه توقع الحدث بالنسبة للمتعاقدين والغير. } \\
& \text { ثانيا : إلا يكون بإمكان المتعاقدين دفع ذلك الظرف أو تفاديه. } \\
& \text { ثالثا : إلا يكون المتعاقدين سببا في حدوث القوه القاهرة. } \\
& \text { رابعا : أن يجعل الظرف الأجنبي القاهر تنفيذ المدين لالتزامه مستحيلا لا مرهقا. } \\
& \text { أولا : عدم امكانيه توقع الحدث بالنسبة للمتعاقدين والغير: }
\end{aligned}
$$

يشترط في السبب الأجنبي لتكييفه قوه قاهرة أن لا يكون بإمكان أحد توقع حدوثه بالنسبة للمتعاقدين والغير على حد سواء فاذا كان بالإمكان توقع حدوث الظرف الأجنبي و أن من الغير (الأجنبي) عن المتعاقدين فأن ذلك الظرف لا يعتبر قوه قاهره ، ومعيار تحديد عدم توقع الضرر أو الظرف الأجنبي معيار موضوعي لا شخصي (10) والأمر متروك للقضاء المدني المختص لتحديد توافر صفه القوه القاهرة في الظرف الأجنبي من

ثانيا : إلا يكون بإمكان المتعاقدين دفع ذلك الظرف أو تفاديه: لإعتبار الظرف الأجنبي قوة قاهرة أن يكون أثثه مما لا يمكن دفعه وتفاديه بالنسبة للمتعاقدين والغير على حد سو اء وتلافي آثار ذلك الظرف ونتائجه مها بذل في ذلك من جهود وعنايه ، وبالتالي يستبعد من نطاق ودائرة الظروف القاهرة كل الظروف الأجنية التي يمكن للمتعاقدين دفعها أو تفاديها و أن كانت غير متوقعه(11). ومعيار عدم القدرة على دفع الظرف الأجنبي هو أيضاً معيار موضوعي لا شخصي أي أن ينظر الى ذات الظرف والسبب الأجنبي لا إلى الميزات الشخصية المتوفره في شخص الملتزم أو غيره(12). ثالثا : إلا يكون المتعاقدين سببا في حدوث القوه القاهرة: يعنى بهذا الشرط أن يكون الظرف الطارئ الخارجي مستقلاً عن إرادة أطراف العلاقة التعاقدية أي أنه لا دخل لإرادة المتعاقدين في حدوث القوة القاهرة، ولذذا سمي الظرف القاهر من قبل الفقه بالظرف الأجنبي (13) هذا الشرط يمليه المنطق والعدالة، وذلك لأنه لو كان للمدين دخل في إحداث الظرف القاهر 
الأجنبي سواء في بفعله أو مساهمته في الفعل لما كان له الحق في الدفع بالضرف القاهر للتحلل من الوفاء بالالتزام.

\section{رابعا : أن يجعل الظرف الأجنبي القاهر تنفيذ المدين لالتزامه مستحيلاً لا مرهقاً :} يشترط كذلك في الظرف القاهر الأجنبي أن يكون أثره على تنفيذ المدين لإلتز امه مستحيلاً لا مرهقاً أي بمعنى أن المدين لا يمكنه الوفاء بالتز امه مها بذل في ذلك من جهود ومها سلك في سبيل ذلك من طرق ومحاولات، والاستحالة هنا هي الاستحالة المطلقة لا النسبية أي بمعنى أنه يستحيل على المدين وعلى غيره من الناس الوفاء بالالتزام إذا تو اجد في نفس الظروف (14).

وخلاصه القول انه متى ما تو افرت الشروط التي أشرنا إليها أعلاه بجتمعه في الظرف الطارئ الأجنبي يمكن في تلك الحالة تكيفه قانونياً على أنه حالة قوه قاهره والاعتداد بها ينتج عنها من أثارٍٍ قانونيه ، والتساؤل المُلحِح هنا مفاده (هل يمكن اعتبار جائحه كورونا (كوفيد - 19) قوه قاهره؟ هذا ما سنجيب عنه في الفرع القادم.

\section{المطلب الثاني: تحديد الأثر القانوني لجائحة كورونا على الالتزام العقدي:}

لتحديد التكييف القانوني الصائب لأثار جائحه كورونا على الالتزام بشكل عام والعقدي بشكل خاص لا بد من نظر تلك الاثار واسقاطها على الشروط اللازم تو افرها لتحقق نظريه القوه القاهرة من عدمه. ان العقد بعدنا ان تحلص قوته الملزمة يصبح المدين ملزما بتنفيذ التزامه قبل الدائن وفي حاله امتناع المدين على القيام بتنفيذ التزامه يجوز للدائن هو الأخر ان يمتنع عن التنفيذ في بجال العقود الملزمة للجانبين وله أن يطلب إجبار المدين على تنفيذ التزامه من خلال اللجوء إلى التنفيذ العيني الجبري الذي ينص عليه القانون مالم يثبت المدين أن هناك ظروف أو أسباب لا دخل لإر ادته فيها تمنعه من الوفاء بالتزامه. أي أن الظرف الطارئ اجنبي خارج عن إرادة المتعاقدين والمدين وبالتالي في هذه الحالة هل يعتبر المدين مقطع في تنفيذ التزامه ويتحمل المسؤولية الناشئة عن ذلك امانه يعفى من تنفيذ التزامه. 
لا بد من الرجوع إلى شروط القوه القاهرة التي اشرنا اليها في الفرع السابق لتحديد مدى انطباق القوة القاهرة على جائحة كورونا من عدمه.

\section{أولا : عدم توقع أطر اف العلاقة التعاقدية لحدوث جائحه (كوفيد - 19 ) أو فيروس كورونا:} لم يكن احد من البشرية يتوقع حدود جائحه ووباء يوما ما خصوصا و ان العالم يعيش في ظل ثوره طبيه وتكنولوجيه عالية المستوى كما أن الصينيون انفسهم لم يتوقعوا ان يجتاح وباء في يوم العالم بدءا من دولتهم فمنذ ظهور الفايروس في الصين و الاعلان عنه رسميا الى منظمه الصحة العالمية في 30 ديسمبر 2020 لم تتخذ الدول اجراءات احترازيه داخليه لأنها لم تكن تتوقع وصول الفيروس إليها لكن وعند زياده الحالات وسرعه انتشار الوباء ووصوله إلى الدول بدأت الدول التي وصل اليها الفايروس باتخاذ إجراءات احترازيه تعددت بدءا من تشكيل خلايا رسمية عالية المستوى لإدارة الأزمة الوبائية والنص على ضرورة التباعد الاجتماعي بين ابناء ججتمع تلك الدول وفرض الحجر الصحي والتزام المواطنين منازلهم وعدم التجوال و التنقل إلا للضرورة القصوى والاستعانة بالأجهزة الشرطية والأمنية لفرض ذلك الحظر ومنع المو اطنين من التنقل المؤدي إلى انتشار الفيروس كل ذلك يؤكد على أن الافراد انفسهم والدول لم يكن يتوقعون وصول الجائحة اليهم أو حدوثها يوماً وبالتالي فان عنصر عدم التوقع متحقق في بالنسبة لجائحة كورونا. ثانيا : أن لا يكون بإمكان المتعاقدين دفع أثثار فيروس كورونا أو تفاديها: أن ما يؤكد هذا الشرط بالنسبة لجائحه كورونا أن الدول رغم ما لديها من إمكانيات وبالرغم من وجود خلايا الأزمة التي تم انشائها وعلى أعلى المستويات لم تستطع أن تحول دون انتشار الإصابة و وصولها إلى أراضيها وشعوبها. فقد بدأت الحالات بالظهور في معظم الدول بالرغم من وجود الإجراءات أي بمعنى أنه رغم تلك الإجراءات لم يستطع أحد تفادي تلك الاثار ومنهم أطراف العلاقة التعاقدية الذين لم يكن بإمكانهم أو باستطاعتهم تلافي حدوث جائحه كورونا أو تلافي اثارها فمن أصيبَ منهم بالفيروس لم يتمكن من مواصلة اعماله وتم وضعه في الحجر الصحي أو في المؤسسات الصحية لتلقي العلاج او من لم تصبه الجائحة إلا أنه رغم 
ذلك ظل يعيش تحت اثارها من فرض حظر التجول ومنع التنقل وعدم خروج الناس إلا للضرورة أي بمعنى تقطعت اوصال أعحالهم و تقطعت بهم السبل فأصبحو اغير قادرين على التو اصل والوفاء بالتزاماتهم المختلفة. ثالثا : أن لا يكون المتعاقدين سببا في حدوث جائحه (كوفيد - 19) ، كورونا فيروس : فيروس كورونا منذ ظهوره في الصين لم يكن احد سباً في وقوعه حتى الأشخاص الذين اصيبوا به وقفوا مذهو لين أمام إصابتهم وكيفية تعرضهم للإصابة بتلك الجائحة، وبالتالي فأن أطراف العلاقة العقدية لم يكون سبب في حدوث الجائحة بل على العكس فقد وجدوا انفسهم فجاه امام وباء يجتاح العالم ويعطل كافه الالتزامات الدولية منها و الداخلية.

\section{رابعا : أن يجعل السبب الأجنبي (جائحة كوفيد - 19 ) تنفيذ المدين لإلتزامه مستحيلاً:} بالرجوع إلى الإجراءات الشديدة التي اتخذت على مستوى المجتمع الدولي كافه وحتى على مستوى الدول منفرده نجد أن جميع الدول لجأت إلى فرض التباعد الاجتحاعي وضرورة التزام الناس في منازها ومر اقبه ذلك من قبل الأجهزة الشرطية بل وحتى فرض حظر التجول ومنع التنقل بين المدن بل ولجأت إلى إغلاق مناطق بعينها أو مدن لتطويق انتشار الفيروس الأمر الذي جعل تنفيذ الناس كافة في ظل هذه الظروف لالتزاماتها مستحيلاً فضلا عن المدين والمتعاقد الذي لم يكن بو سعه الايفاء بالتزاماته في ظل هذه الظروف. فإذا رجعنا إلى الالتزام الدولي فأن جميع وسائل التواصل بين الدول أصبحت شبه مقطوعه إلا ما كان منها ضرورياً وصحياً وقطعت وسائل النقل الدولي فأعلنت كافه المطارات إغلاقها وقامت شركات الطيران بتوقفها عن العمل لفتره مفتوحه لم تحدد نهايتها فتقطعت وسائل الشحن والنقل بالنسبة لأغلب الالتزامات الدولية فضلا عن الوطنية فلم يكن بوسع الأشخاص التنقل من مكان إلى أخر للإيفاء بالتزاماته فاصبح تنفيذ الالتزام في ظل هذه الظروف مستحيلا على أطر اف العلاقة التعاقدية بناء على ما تم تقديمه يمكن تصنيف جائحه كورونا وتكييفها قانونياً على انها (قوه قاهره) ظرفا أجنبيا يمثل قوه قاهره وفقا لأحكام القاعدة العامة في القوانين المدنية وما يترتب عليها من نتائج وأثار قانونيه تتمثل في 
إنهاء الالتزام وزوال المسؤولية العقدية بقوه القانون وعدم تحميل أطر اف العلاقة العقدية تعويض جراء ذلك، ويمكن تأييد ما ذهبنا إليه بالأسانيد القانونية الآتية: أولا : إن انطباق حالة القوة القاهرة على فيروس كورونا يجعل الالتزام مستحيل التنفيذ وهو بذلك يكو ن حالة مادية تنفي عن المدين التعويض عند الاخلال بالتزامه التعاقدي، ومن العقود التي تنتهي فورا هي عقود السفر والسياحة وتأجير السيار ات وغيرها من العقود الدولية والوطنية. ثانيا : إعلان أغلب الدول والمنظات الدولية وعلى رأسها منظمه الصحة العالمية(15) أن جائحة كوفيد - 19 (فيروس كورونا) هي قوه قاهره عالميه وما يؤيد ذلك إصدار القضاء الفرنسي " محكمة الاستئناف في مدينة كولمار الفرنسية " حكم ينص على أن جائحة (كورونا) قوة القاهرة، وذلك في حيثيات قرار اصدرته في 12 آذار الجاري كما أكدت على أن القرار غير قابل للمعارضة والمراجعة إلا عن طريق التمييز ثالثا : أن القول بغير القوه القاهرة كتكييف قانوني لجائحة كورونا سيجعل المدين متأخرا بالتنفيذ طيلة مده عدم التنفيذ وبالتالي يسمح بمطالبته الغرامات التأخيرية التي قد تصل إلى مبالغ كبيره جداً خصوصا في ظل العقود الدولية فقد بلغت خسائر الصين على سبيل المثال 20 مليار دولار في الفترة القليلة الماضية.

رابعا : أن القول بأن جائحة (COVID 19) أو فيروس كورونا ليست قوه قاهره سيؤدي إلى وجود السيل من الدعاوى القضائية أمام القضاء للمطالبة بالتعويض وإعمال المسؤولية التعاقدية يوازي في سرعته سرعة انتشار الفيروس خصوصاً و أن أغلب شركات الطيران على سبيل المثال أعلنت عن إلغاء آلاف رحلاتها الجوية وتسريح أعداد كبيره وضخمه من العاملين لديها حتى شركات الكبرى لجأت إلى مثل هذه الإجراءات للتقليل من آثار الجائحة خامسا : لجوء دول كبرى مثل الصين والولايات المتحدة الى منح شهادات القوه القاهرة للشركات الدولية التي لا تستطيع الوفاء بالتزاماتها في ظل انتشار فيروس كورونا وما خلفه من آثار فقد أعلنت هيئة 
تنمية التجارة الدولية الصينية أنها ستمنح شهادات (القوة القاهرة) للشركات الدولية التي تناضل من أجل التأقلم مع تأثيرات فيروس كورونا خصوصاً تلك التي ليس بإمكانها تقديم أدلة موثقة لإثبات التأخير أو تعطل وسائل النقل وعقود التصدير وغيرها.

\section{الخاتمـة}

تو صل الباحث من خلال الدراسة الى النتائج والتو صيات الآتية:

النتتائج:

1 - يلحظ ومن خلال التعاريف التي أوردها المختصون في المجال الطبي أن المقصود بالجائحة (الوباء) هي الأمراض أو الفيروسات المعدية شديدة الانتشار بين البشر على مستوى دوله أو أكثر سواء في قارة

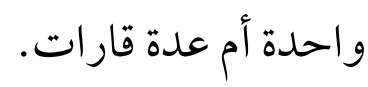

2- القوة القاهرة وفقا للقاعدة العامة في القانون المدني هي (سبب أجنبي طارئ على المتعاقدين غير متوقع الحدوث وليس بوسع أحد تلافي نتائجه أو تفاديها يجعل تنفيذ المدين لإلتز امه مستحيلاً). 3- بالرجوع للقاعدة العامة في القانون المدني العراقي ووفقاً لنص المادة ( 11 ) من ذات القانون فأنه يمكن تكييف جائحة (COVID - 19) قانونياً بأنها سبب أجنبي طارئ يمثل حالة قوة قاهرة يجعل تنفيذ المدين

$$
\text { لإلتز امه مستحيلاً. }
$$

4 - أن أهم أثثر يترتب على تكيف الجائحة كقوة قاهرة يتمثل في انهاء الرابطة العقدية وانقضاء التزام المدين بقوة القانون مع عدم مطالبته بمبالغ تعويضية أو فوائد تأخيريه جراء عدم التنفيذ أو التأخر فيه.

\section{التوصيات:}

1 - يدعو الباحثان المشرع العراقي الى معالجة حالة القوة القاهر بنص خاص في القانون المدني يحدد ماهيتها وشروطا ويعالج آثارها. 
2- يدعوا الباحثان القضاء في الدول العربية خاصة الم تحديد التكييف القانوني للجائحة بها يعيد التوازن العقدي ويمنع قيام المنازعات بين المتعاقدين جراء أثنار الجائحة فيجد القضاء نفسه أما سيل من الدعاوى القضائية جر اء تلك الآثار.

3 - يدعوا الباحثان القائمين على شؤون التعاقد وكافة الشؤون التجارية والصناعية وغيرها من بجالات العقود ذات الالتزام الدولي في الدول العربية إلى اتخاذ إجراء مناسب لتجنيب الأشخاص الطبيعية و المعنوية المتعاقدة والمترتب بذمتها التزام دولي لا تستطيع الإيفاء به في ضل فيروس كورونا اثار الجائحة على غرار الإجراءات التي قامت بها الصين والولايات المتحدة الأمريكية حيث منحت الشركات شهادة قوة قاهرة.

\section{قائمهة المراجـع}

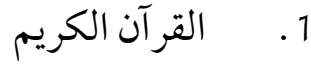

2. الفضل، منذر ، الوسيط في شرح القانون المدني ، ط1 ، دار أراس. أربيل. 2006. 3. الحكيم، عبد المجيد وأخرون، القانون المدني ومصادر الالتزام ، دار السنهوري ، بيروت ، 2015. 4. مؤسسة الهنداوي، ديو ان الفرزدق ، مؤسسة الهنداوي ، لندن ، 2019، 25. 5. نبيل اسماعيل عمر ، سلطة القاضي التقديرية في المو اد المدنية والتجارية ، مطبعة أطلس ، الإسكندرية ، 1995.

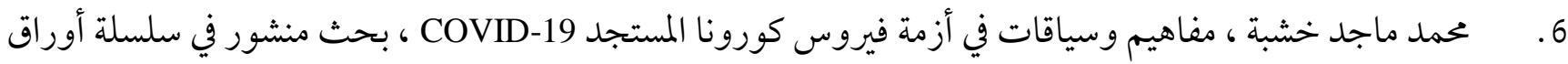
الأزمة ، (عدد خاص بجائحة كورونا) ، القاهرة ، 2020

7. خالد مصطفى ، دروس الفيروس ، بحث منشور في مجلة الارشيف العربي العلمي: (عدد خاص بجائحة كورونا) ،

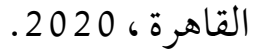

8. ياسر باسم ذنون ، القوة القاهرة وأثرها في أحكام قانون المرافعات المدنية ، بجلة الر افدين للحقوق: المجلد 10 ، العدد (36)، جامعة الموصل ، 2008 ، ص200. 9. أمينة رضوان ، مدى مساهمة فيروس كورونا في أنهاء العلاقة الشغلية ، مجلة الباحث: دون مجلد (17) ، الرباط ، 
10. محمد شتا أبو السعد ، مفهوم القوة القاهرة ، مجلة مصر المعاصرة: دون بجلد ، العدد (393) ، 1989. 11 1. القانون المدني العراقي رقم (40) لسنة 1951م، دار السنهوري ،بيروت ، 2015. 12. https://www.almaany.com/ar/dict/ar-ar .

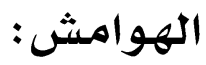

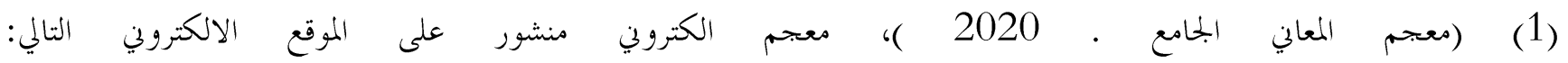

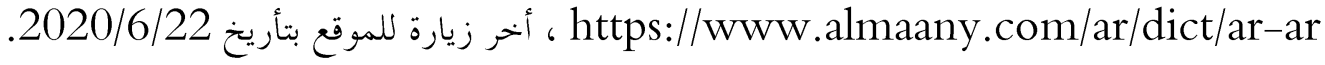

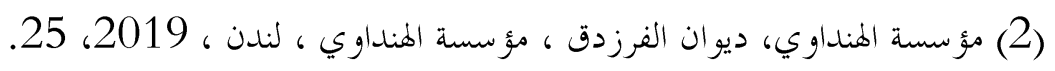
(3) شعر أبن الرومي.

(4) خالد مصطفى ، دروس الفيروس ، بحث منشور في بحلة الارشيف العربي العلمي: (عدد خاص بجائحة كورونا) ، القاهرة ، 2020 ،

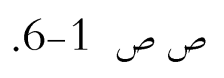

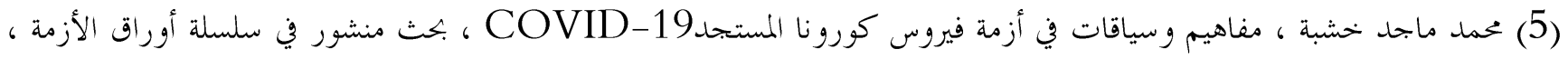

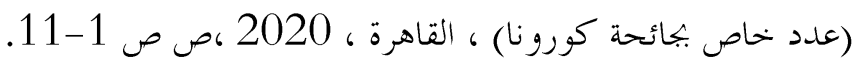

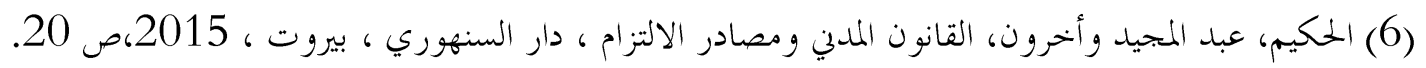

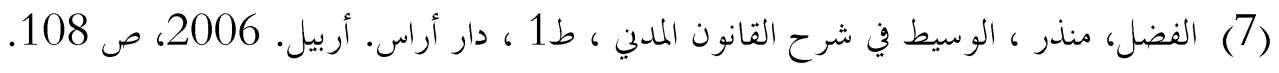

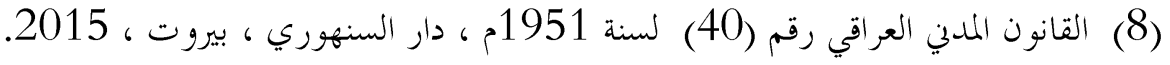

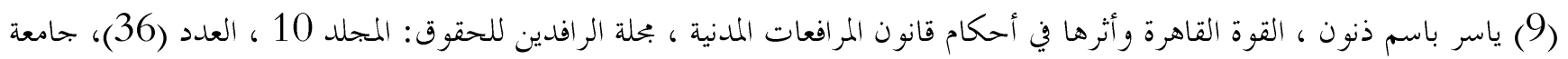

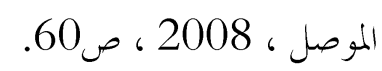

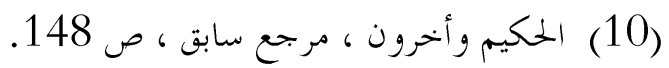

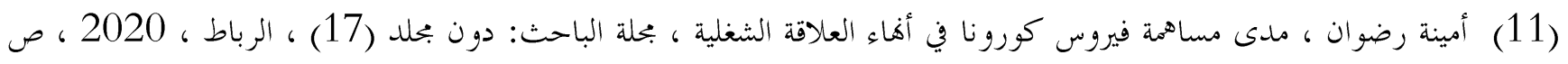

(12) محمد شتا أبو السعد ، مفهوم القوة القاهرة ، مجلة مصر المعاصرة: دون بحلد ، العدد (393) ، 1989 ، ص73. (13)

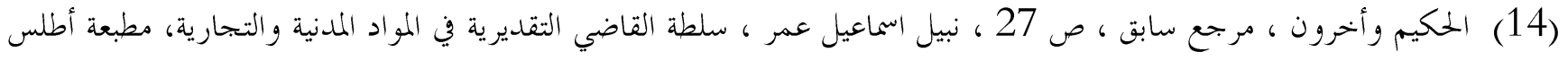

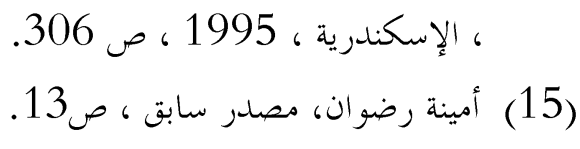

